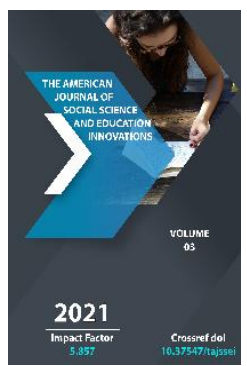

\title{
On Some Aspeects Of The Development Of Pilgrimage Tourism In The Renewed Uzbekistan
}

\author{
Bakhrom Orzikulov \\ Independent Researcher Of The National University Of Uzbekistan
}

Journal Website:

http://usajournalshub.c om/index,php/tajssei

Copyright: Original content from this work may be used under the terms of the creative commons attributes 4.0 licence.

\section{ABSTRACT}

The article describes some aspects of the development of pilgrimage tourism in the renewed Uzbekistan, including the ongoing regulatory and legal mechanisms for the further development of the industry, the socio-spiritual basis. It describes the large-scale measures being taken to further enhance the international image of this area.

\section{KEYWORDS}

Renewing Uzbekistan, tourism, pilgrimage tourism, culture, spirituality, strategy, decree, reform, foreign, tourist, history, heritage, sacred sites, international forum.

\section{INTRODUCTION}

It is known that, tourism is considered important in social and spiritual life of country, economic development and raising its prestige all over the world. Every country tries to develop varieties of tourism according to its inner opportunities, capability, geographical position, socio-economic condition, its history and today. At present, various types of tourism are growing: ecotourism, sports tourism, 
excursions tourism, extreme tourism, gasronomic and pilgrimage tourism.

Uzbekistan as an important civilization cradle contributed to the growth of the world significantly. The most effective and newest type of tourism is pilgrimage tourism. It is a good source of improving economical situation of each area, forming social and spiritual lifestyle of people. In the next years, in our republic promoting tourism, registering cultural heritage objects to official list of country, using wide range of tourism opportunities are experienced and translated into practice. Its clear evidence is that "The first international forum of pilgrimage tourism" was organized in Bukhara, on February in 2019'.

Uzbekistan has got many chances to prosper domestic and international tourism. It has more than 8200 cultural heritage objects ${ }^{2}$, nation's rich culture, long period of history, archeological objects, architectural monuments, magnetic nature always attracts travelers. The most important it has warmhearted, friendly and hospitable nation. All of the abovementioned serve as a reason for tourists to come Uzbekistan. Uzbekistan with its touristic possibilities noted as the $1^{\text {st }}$ place in Central Asia , $10^{\text {th }}$ or $15^{\text {th }}$ place in the world 3 .

The branch of tourism which is in the third aspect of the National Actions Strategy on five priority development areas for 2017-2021 in renewing Uzbekistan, the component of the service area in further growth and

\footnotetext{
1 "The first international forum of pilgrimage tourism". Bukhara. February 22, 2019. www.gazeta.uz ${ }^{2}$ President Shavkat Mirziyoyev's Address to the Oliy Majlis.

3 Khujamov M, Lafasov M, Mulladjanova R. Historical regional studiesand tourism. - T .,2014, 87p
}

liberalization of the economy has been paid separate attention to developing. Likewise, the president of the republic of Uzbekistan, Shavkat Mirziyoyev in the address to the Oliy Majlis emphasized on the field of tourism that as a result of the establishment of the visa-free regime for citizens of the 86 and simplified visa regime for 57 states, 6.7 million foreign tourists visits, compared to 2017, were noted that 4.7 million or 3.3 times more than 2016. One of the most important missions of government is increasing the number of tourists to 7.5 million, the significance of developing capable pilgrimage and medical tourism is also noted separately.

According to the researchers, inclusion of Uzbekistan in the list of recommended countries for travel by several prestigious foreign mass media in 2020, has been showing that we need to make effective use of opportunities in the field tourism. In view of the above, it is necessary to coordinate the development and monitoring of national and regional programs for the integrated development of domestic, inbound and outbound tourism in our country, to accelerate the development of a wide range of tourism in accordance with international standards ${ }^{4}$.

Decree of the Republic of Uzbekistan "On measures to further develop the tourism industry in the Republic of Uzbekistan" in August 13, in 2019 triggered growing all fields of tourism, also pilgrimage tourism in Uzbekistan. In accordance with this decree the followings were pointed as significant tasks for

\footnotetext{
${ }^{4}$ Muminov A. The issues of ecology tourism in Uzbekistan..//The issues regarding to historiography of Middle Asia.// The collection of International scientific conference on issues of the history of people in Middle Asia. -T., 2020421 p
} 
the further development of the field as well as other areas of tourism:

- Part of the cost of charter flights from foreign countries to Uzbekistan, for each foreign tourist, if he stays in the country at least five nights, in the amount of 20 US dollars, and in winter ( from November 20 to February 20) in the amount of 50 US dollars are equally funded by the State budget of the republic of Uzbekistan and Extra-budgetary Tourism Support Fund under the State Committee for Tourism Development;

- International Filmcompanies' expenses ( by $20 \%$, for a product no more than 300 ooodollars) of creating audiovisual productions(movie, tele and videofilm, video, cartoon, animation) in the area of Uzbekistan is funded by State budget of the Republic of Uzbekistan;

- Extra-budgetary Tourism Support Fund under the State Committee for Tourism Development support with grants of $30 \%$ of the project cost, but not more than 3 billion soums, for the production of full-length feature films, short feature films, chronicle documentaries about historical and mythological figures of Uzbekistan;

- Growing the volume of credits to the field of service in tourism, especially, lucrative pilgrimage tourism, on the base of measurements related to encouraging the development of this field by giving extra privileges to sole proprietors establishing the restaraunts specialized in foreign meals or separate direction, likewise, karaoke halls and touristic enjoyment places by business organizations in the area of the republic(except Tashkent);

- Some of these expenses are funded by Extra-budgetary Tourism Support Fund under the State Committee for Tourism Development, 10 million soums for every project;

- It is planned to sell only domestically produced souvenirs on the territory of UNESCO World Heritage Sites and stateprotected historical or cultural monuments. In order to accelerate the development of domestic and foreign pilgrimage, from November 1, 2019, the gatherings of citizens with the highest tourism potential in the territory of Uzbekistan (from towns, villages, auls and towns, towns, villages and auls to villages) This is evidenced by the fact that the meetings of citizens granted the status of "Tourism Village" or "Tourism Village" are included in the state programs "Obod Qishloq" and "Obod Mahalla" and a number of practical measures have been taken in recent years.

- Based on the experience of tourist areas in Bukhara and Samarkand, step by step planning tourist areas in Urgench, Tashkent cities and Fergana region, a mountain cluster in the Bostonlyk district of the Tashkent region are organized. Measures are being done on attracting foreign investments to the area of tourism and mountain tourism clusters, inviting leading hotel brands for building new hotels or giving the authority of local hotels to them.

'On priority measures to mitigate the negative impact of the coronavirus pandemic and global crisis phenomena on the economy", President's decree which was signed 19 March 2020, personal income tax for individual entrepreneurs in the field of tourism (family guest houses, guides, craftmen) has been reduced by 30 percent. Likewise, for those who 
were forced to cease their works during the quarantine period, strictly defined amount of income tax and social tax payments was discontinued. In this regard, entrepreneurs can inform tax organs about liquidation of their activities online; debts regarding to credit payments(hotels, tour operator transport logistics enterprises) was postponed.

Besides that, concessions on export-import operations (in the case of total export receivables not exceeding $10 \%$, the implementation of guaranteed unpaid exports, foreign trade operations in exchange for the repayment of receivables, the purchase of technological equipment and raw materials); Penalties for overdue receivables on foreign trade operations (for tourist services sold to foreign partners) will be suspended; tax audits were canceled.

According to the decree, pilgrims will be able to repay loans totaling 5 trillion soums to tourism operators, hotel businesses, transport and logistics companies and other enterprises of the tourism industry, as well as businesses facing financial difficulties due to restrictions on foreign trade operations. The delay (excluding fines) was extended until October 1 , 2020. The adoption of the decree was an important factor in the development of this sector, the broad involvement of citizens, especially young people.

Also, the adoption of the decree on February 3, 2021, the President of the Republic of Uzbekistan 'On measures to further develop domestic and pilgrimage tourism in the Republic of Uzbekistan" was an important factor in the development of this sector, the broad involvement of citizens, especially young people. According to the decree, during the celebrations of the national holiday of Navruz, Independence Day and New Year, as well as the religious holidays of Ramadan (Eid al-Fitr) and Eid al-Adha (Eid al-Adha), days that are not processed due to additional and transfer are set for a period of not less than three days. "Family travel vacation" system was established which is considered travelling with parents, relatives, old persons and teachers during not less than 5 working days. In this regard, family travel vacation was given from annual main holiday and was considered to fulfill according to community contracts with the agreement of employer.

In the framework of further development of pilgrimage tourism, expansion of financial opportunities of the industry, from March 1, 2021, citizens of the Republic of Uzbekistan and non-permanent residents of the Republic of Uzbekistan will be provided with accommodation from the Cabinet of Ministers for each day they stay. At the same time, the tourist (hotel) collection will be used to promote and encourage domestic tourism, to finance measures to ensure the employment of accommodation during the low tourist season.

In fact, pilgrimage tourism, that is, pilgrimage to the holy places, consists of two main directions, namely, the direction of enlightenment, pilgrimage and religious tourism. In this term, the country has a high level of potential in this area of tourism. To add to it, this is evidenced by the fact that keeping one of the most valuable Holy Quran in the Islamic world- Hazrati Usman Mushafi in Uzbekistan, Imam and teacher of hadith scholars Muhammad al-Bukhari, many followers of the Naqshbandi sect have grown up in our land and have their last homes here, 
as well as the existence of a number of religious centers.

Pilgrimage tourism serves not only for economic growth, but also employment of the population and improving living standards. There are more than 1.6 billion muslims in the world, they live in different regions throughout the world. Attracting the citizens of these countries to pilgrimage tourism creates great opportunities to Uzbekistan.

Every year thousands of tourists from all over the world visit the historical and sacred places of the Republic. International events, seminars and conferences are being organized. As one of the practical steps of this direction, here it should be noted that the I International Forum of Pilgrimage Tourism was held in Bukhara and Samarkand on February 21-23, 2021. At the first International Pilgrimage Tourism Forum many mass media representatives from Europe and Asia visited our country. These include EuroNews (France) and Al Jazeera (Qatar), AlAhram Al-lqtisadi (Egypt), Diplomatic News (Pakistan), Kommersant (Russia), Al-Wajhat. (Oman) and Al Hayat (Saudi Arabia).

The participants of this international pilgrimage tourism forum had the opportunity to visit the sightseeing places of our country for three days and get acquainted with the conditions created here for tourists. They also received valuable information about the work being done to turn Uzbekistan into a center of pilgrimage tourism and the projects which are being implemented. In 2021, advocacy works have been carried through in order to promote the image of our country as a center of Islamic civilization exhibitions and conferences which were taken place in Dubai (UAE), Alanya (Turkey), (Kazan), Russia, Jakarta (Indonesia) and Singapore, as well as TRT Avaz (Turkey), Trans7, NetTV, SCTV (Indonesia), AlHijrah (Malaysia), HalalTrip (Singapore) and other foreign media platforms. The "Shamoili Muhammadiya" International Poetry Competition will be held at the Imam al-Termizi Complex in Termez, the "Islamic Calligraphy and Painting" Competition will be held in Bukhara, and the "Islamic Calligraphy Gallery" and the "Minarai Kalon" International Azan Competition and an international scientificeducational conference "Spirit of the Silk Road" are being planned to held.

This year in Samarkand there will be conferences on international hadith "Imam Bukhari" and "History of the most ancient and rare manuscripts of Sahih Bukhari in world libraries", in Tashkent "Modern research of the scientific heritage of Imam Moturidi", in Karshi "Abu Muin Nasafiy" Central Asia scholars and it is also noteworthy that a conference of scholars on "Contribution of Termez scholars to Islamic civilization and world civilization" will be held in Termez, and foreign experts will be invited to these events too. In particular, about the organization of the grand final in Uzbekistan among the winners of the competition of the Quran memorizers and students of Hadith in Uzbekistan, the organization of a calligraphy event for access to the Guinness Book of Records in the Central Park of Jakarta in Tashkent "Osman Mushafi" and photos (videos) of the organization of exhibitions and the preparation of promotional materials, including projects and activities aimed at advocacy through social media platforms (Facebook, Twitter, Tik-tok, Instagram).

Generally, Uzbekistan is a country with great potential for pilgrimage tourism. Particularly, 
the measures taken in renewing Uzbekistan in this area, determine a new development strategy for the industry. Based on the ideas and comments above, the article gives the following suggestions for further development of the industry:

- Effective use of the tourist potential of existing shrines, ensuring the rapid development of modern business, financial and tourism infrastructure, improving the quality of services provided to the population and foreign visitors;

- To create a modern architectural image of the shrines while keeping the national calorie content, and, additionally, to attract more international, foreign and local financial institutions and investors;

- Further improvement of the restoration and conservation of shrines, cultural heritage sites and the creation of the necessary conditions for the population and foreign guests, further expansion of the presentation of the potential of pilgrimage tourism in Uzbekistan in foreign countries;

- Organizing free trips for prominent religious scholars of Muslim countries to Uzbekistan, creating opportunities for them to get acquainted with the opportunities of pilgrimage tourism in Uzbekistan and the holy shrines;

- The organization of regular visits of citizens of our country to the holy shrines of Uzbekistan before going to the Hajj and Umrah, etc.

\section{REFERENCES}

1. President Shavkat Mirziyoyev's Address to the Oliy Majlis//Xalq So'zi.25.01.2020.
2. The President's Decree-5969 'The first measures to measure the negative effects of the coronavirus pandemy and the global crisis on the economic sector"//New Uzbekistan.20.03.2020.

3. Khujamov M, Lafasov M, Mulladjanova R. Historical regional studiesand tourism. $-\mathrm{T}$ .2014, 87p

4. Muminov A. The issues of ecology tourism in Uzbekistan..//The issues regarding to historiography of Middle Asia.// The collection of International scientific conference on issues of the history of people in Middle Asia. -T., $2020421 \mathrm{p}$

5. The first international forum on pilgrimage tourism. Bukhara. February 22, 2019. https://www.gazeta.uz.

6. https://uzbektourism.uz/cyrl/newnews/vie $\mathrm{w}$ ?id $=1527$ 